\title{
Heartrending or Uplifting: The Ethiopian Urban Land Tenure System Reform and Its Reflection on Tenure Security of Permit Holders
}

Brightman Gebremichael

Faculty of Law, University of Pretoria, South Africa

\begin{abstract}
In this article, I reflect on the implication of the urban land tenure systems of the three political regimes of Ethiopia on the objective element of land tenure security of urban landholders, particularly, permit holders. The objective element of land tenure security can be assessed in terms of clarity and breadth, duration, assurance, and enforceability of land rights. On these foundations, I argue that the objective element of tenure security of urban landholders in Ethiopia has been reduced with each subsequent regime. The Imperial regime's urban land tenure system affected the objective land tenure security of urban landholders in terms of enforceability of land rights particularly limiting the right to appeal to a presumably independent court of law with regard to the amount of compensation awarded for the loss of land rights through expropriation. The Derg regime's urban land tenure system, on the other hand, had narrowed the breadth of land rights to possessory right; it introduced other grounds in addition to expropriation, by which a landholder could lose his land rights, it adopted a vague and broad understanding of "public purpose" for expropriation, and it introduced a compensation scheme that left a landholder compensated inadequately; and it totally prohibited bringing a legal action in presumably an independent court of law against the government. Even more, the post-1991 urban land tenure system has perpetuated the objective land tenure insecurity of permit holders by making the land rights unclear until the enactment of regulation; and to be valid for a definite period of time by mandatorily demanding its conversion to lease system.
\end{abstract}

Keywords Permit holder, urban land tenure system, land tenure security, Ethiopia

\section{Introduction}

In countries like Ethiopia, the issue of land holds an immense and significant position in the economic, political, and social life of human beings. This holds true since land is fundamental to the lives of every society being the basic sources of food, shelter, and income which is the cardinal factor of production and store of wealth. Not only is land a material and productive resource that enables survival, livelihoods, and agricultural production, but it is also an important symbolic resource that heavily influences status, rites of passage, and identity that excites intense emotional and psychological attachment in a way that services, materials, and finance do not.

However, this centrality of land can be realized only when the land tenure system ensures the land tenure security of its holder. This is due to the fact that the pervasiveness of tenure security has a tendency to enhance economic growth, reduces environmental degradation, and plays a key role in poverty reduction, and good governance and democratization (Deininger, 2003). Accordingly, a land tenure system that governs the manner in which land is held, used, and transferred being defined customarily or statutorily (FAO, 2002) should promote the objective elements of tenure security achieved through clear definition of land rights, provision of adequate number, and the most important land rights, limiting the grounds by which the land rights are lost upon the payment of just compensation, and provision of an opportunity for landholder to enforce land rights in an independent court of law (Deininger, 2003; Seifu, 2009). 
In Ethiopia, the history of the urban land tenure system has passed through three notable political regimes. These are the urban land tenure system of Imperial regime, Derg regime, and the Ethiopian Peoples' Revolutionary Democratic Front (EPRDF) regime. The implication of these land tenure systems on objective tenure security of urban landholders in general, and permit holders (persons who have acquired urban land in Ethiopia before the introduction of lease system) in particular, has yet to be examined fully. Thus, this article is a call for that.

\section{History of Ethiopian Urban Land Tenure System and Security}

The historical contours of the urban land tenure system and security of Ethiopia can be studied by categorizing into three different political regimes. Consequently, it can be classified as Imperial regime, Derg regime, and the EPRDF regime urban land tenure system. The purpose of exploring the urban land tenure system of the different regimes is to evaluate the extent to which each land tenure system has granted the objective tenure security of urban landholders, and to appreciate whether there has been improvement in the land tenure systems' ability to ensure objective tenure security with the change of the political regime. Nevertheless, the analysis here is limited to the statutory defined land tenure systems only.

\section{Urban Land Tenure System and Tenure Security of Imperial Regimes}

Unlike the recent situation, available historical accounts reveal the fact that the pace of urbanization during the Imperial regimes was relatively slow, making Ethiopia one of the least urbanized countries in the world (WeldeGebriel, 2005). The main reasons for this were war with neighboring countries including, civil war, recurrent drought and famine, disease, and terrible governance (WeldeGebriel, 2005). Furthermore, the country's history of agricultural self-sufficiency which has supported rural peasant life, and the absence of a permanent capital city in the country for a long period of time affected the slow pace of urbanization (Pankhurst, 1961). However, in the seventeenth century, the lack of a permanent capital city in the Ethiopian history, which was witnessed long after the abandonment of Aksum, was changed with the establishment of Gondar by Emperor Fasiladas (who ruled from 1632 to 1667) as a permanent capital and city of administration in the year 1636, which have produced a more stable and settled type of life than had existed before (Pankhurst, 1966). Emperor Fasiladas and his successors were also able to erect numerous castles and public buildings, which had immensely contributed to the emergence of Gondar as a fixed and permanent city that reverses the previous roving nature of the then rulers and their constant change of center of administrations (Pankhurst, 1961). Particularly, at the end of nineteenth century, it was stated that "the total number of houses built in Gondar was estimated to be around 10,000 which further was estimated to accommodate a total population of around 60,000-70,000, which in fact was far greater than that of any other town in the area" (Pankhurst, 1961).

Accordingly, the establishment of Gondar as a stable capital city is also said to have led to allotment of land in the area by the government to the principal lords where a very high concentrated form of landownership came into existence along with the development of private ownership of land (Pankhurst, 1966). However, there was no written law that indicated the adoption of private ownership of urban land unless it was via customary rules.

However, the major change in the history of urbanization and urban land tenure system of the country in the Imperial regimes came along with the birth of Addis Ababa as a capital city of Ethiopia, in the year 1886 by Emperor Menelik II (Markakis, 1974). Particularly, the promulgation of the 1907 decree had paramount importance. The 1907 decree had duly recognized private ownership of land that allowed wider right in the use, inheritance, and sale of urban lands (Pankhurst, 1966). The edict was mainly declared by the Emperor to give security of land right and to authorize 
and enable those of countrymen and foreigners to buy land in the town of Addis Ababa according to the law (Pankhurst, 1966, Article I). It was enunciated in this edict that both government and individual landholders could sale urban land under their ownership right, save in both cases that the value of the land is assessed by the government (Pankhurst, 1966, Article II and V). Especially, when individuals' sale or buy land, this edict articulated that it must be done with the presence of government representatives and two witnesses, which had to be further corroborated by a certificate that had to be sealed and be issued by the government with payment to be effected for the seal and for the price of the land to the government (Pankhurst, 1966, Article X, XII, XIII, and XIV). More interestingly, any sale of land was expected to be mapped by engineers a copy of which had to be deposited in the cadastre of Addis Ababa (Pankhurst, 1966, Article VI).

Moreover, it is also of paramount importance to note at this juncture that this edict empowered the government to dispossess an individual of his holding whenever doing so was essential for the orderly development of the city and with giving compensation that had to be determined by the then experts (Pankhurst, 1966, Article XXV). Any dispute regarding land was also made to be resolved by a judge in accordance with the accepted laws of the country and when doing so was impossible, through applying Napoleonic Code (Pankhurst, 1966, Article XXXII). Hence, from the perspective of objective tenure security, it can be argued that the 1907 decree had ensured the tenure security of the urban landholders. This is because the decree had provided urban landholders with wider land rights; it had limited the loss of the land right only for public purpose with payment of compensation; and it also empowered the landholders to enforce their land rights through judges.

In the Emperor Haile Selassie's regime as well, the urban land tenure system had followed Emperor Menelik II in accrediting private ownership of land. For instance, the 1931's first historical Constitution of the Emperor, clearly endorsed private landownership right of individuals that guaranteed landholders not be deprived by any one of the movable or landed property they hold unless it is of for public purposes (The Constitution of Ethiopia, 1931, Article 27). Moreover, regarding the obligation that landowners assume, it was stated under the 1932 Decree issued by the Emperor that while those landowners who built a house and rented it should pay annual income tax, those landowners who built a house and who never rented it for others were relieved from payment of income tax and were only obliged to pay annual land tax (Pankhurst, 1966). Furthermore, save that compensation is given to those whose land right is affected by the government, expropriation of privately owned land for different public purposes, such as market, churches, military operations, railways, or for other similar purposes was also specifically articulated under the 1932 Decree. This legal instrument had adopted the narrower definition of public purpose indicating that the matters for private land right are compulsorily acquired for purposes from which the public can drive a direct benefit.

In the same fashion, two main legal instruments adopted later recognized private ownership of urban land. Especially, the 1955 Revised Constitution of the Empire of Ethiopian had allowed every citizen to own and dispose of private property, which mainly included land (The Revised Constitution of the Empire of Ethiopia, 1955, Article 44 and 130 (d)). Similarly, the 1960 Civil Code of the Empire of Ethiopia also has duly recognized private landownership right of individuals (The Civil Code of the Empire of Ethiopia, 1960, Article 1535-1552).

Generally, when we look at the urban land tenure system of Emperor Haile Selassie's regime in light of objective tenure security, it can be concluded that it ensures the tenure security of landholders. This is because the components of objective tenure security that have been seen earlier were again fulfilled in the Emperor Haile Selassie's regime urban land tenure system. By adopting private ownership of urban land, it enabled the landholders to have clearly defined all the bundles of land rightsfull property rights which includes (i) the right to use the asset in any manner that the user wishes, 
generally with the caveat that such use does not interfere with someone else's property right; (ii) the right to exclude others from the use of the asset; (iii) the right to derive income from the asset; (iv) the right to sell the asset; and (v) the right to bequeath the asset to someone of your choice (Alston, Harris, \& Mueller, 2009). Moreover, the duration - the length of time for which these rights are valid-is not limited, and it is possible to exercise them for indefinite period of time.

On top of these rights, to ensure the assurance of the land rights, the then urban land tenure system required the expropriation of land to be done for "public purpose" which was defined narrowly to be beyond obtaining of financial gain. It also required payment of adequate compensation equivalent to the actual damage, and it authorized the landholder to appeal to a court of law in relation to the amount of compensation (The Civil Code of the Empire of Ethiopia, 1960, Article 1463-1477). In addition, with regard to disputes other than expropriation, the landholder was entitled to take a court action to ensure the enforceability of their land rights.

The problem with the Imperial regime urban land tenure system was in terms of access to land. The extensive granting of land was made to the nobility, chiefs, and other followers of the then rulers. The situation led to the high concentration of urban land in the hands of few landlords. This is evidenced by, for instance, from a survey made on 212 square kilometers of land in 1966, which is made in Addis Ababa, it was found out that 58 percent of the total area was owned by 1768 large proprietors each within 10,000 square meters, or an average of 71,000 square meters per owner, whereas 24,590 small proprietors were found out to own less than 10,000 square meters of land accounting only 7.4 percent of land belonged to the government and foreign embassies or legation (Pankhurst, 1966). Moreover, an estimate made in 1966 in Addis Ababa showed that "less than five percent of the population of the city-owned 95 percent of the land in the city' and ' $60 \%$ of the occupied housing units in the city in habited dwellings were rented rather than owned by their occupants in the late 1960's" (WoldeMariam, 1970). Hence, this clearly shows how ownership of land was immensely concentrated into the hands of few individuals' landlords.

\section{Urban Land Tenure System and Security of Derg Regime}

In 1974, the Imperial regime of Haile Selassie faced a challenge from the forces of political change calling for "land to the tiller," and was overthrown by a creeping coup d'état of the Soviet-backed communist military junta known as the Provisional Military Administrative Council (PMAC), more commonly referred to as the Derg (Bodurtha, 2011; Teklu, 2005). Following the overthrow of the Imperial regime, PMAC took different actions that drastically altered the social, political, and economic structure of Ethiopia (Cohen \& Koehn, 1978). One such measure that the Marxist-oriented government implemented was the urban land tenure system that made formal change in the nature of urban land rights in addition to changes in the duties and restrictions of land rights holders, which were influenced by a radical communistic ideology.

In fact, the examination of the cause for the rebellion-related with the land question, reveals that the urban land tenure system of the Imperial regimes had no significant problems. Because the slogan "Land to the Tiller" which brought the Derg regime to political power required the regime to abolish the Imperial regime's rural land tenure system and to come up with a tenure system that grants land rights to the tiller. However, the Derg regime introduced a change on the urban land tenure system as well. Then, the question here is whether the changes introduced in the urban land tenure system during the Derg regime solved the problem faced by the urban dwellers during the Imperial regime-that is, access to land-and whether it further enhanced the urban land tenure security. 
The change with regard to the urban land tenure system was made on July 26, 1975 with the issuance of Proclamation No. 47 of 1975, the "Government Ownership of Urban Lands and Extra Houses Proclamation." It is a far-reaching and complex law with the potential to bring about radical changes in urban society. At the heart of the proclamation was nationalization of all urban land without compensation and promulgating public ownership of land, including urban land (Urban Land Proclamation No. 47/1975, 1975, Article 3(1) and Article 13(1)). In addition, while private ownership of urban houses was not completely terminated, an individual or family could no longer own more than a single dwelling house. All "extra" houses became government property (Urban Land Proclamation No. 47/1975, 1975, Article 3(2)).

The proclamation in its preamble provided a number of reasons for this measure. First, a handful of urban landlords are held to have obstructed urban planning, development, and improvement in urban living conditions through land speculation and abuses of economic and political power. Second, the owners of urban dwellings and businesses are charged with exploiting tenants and evading taxation. Finally, the preamble maintains that nationalization of urban land and houses is essential for careful planning and resource utilization, the extension of secure housing facilities to poor urban dwellers, and improved urban conditions.

These justifications for changes in urban land tenure system sought to solve the problem of access to land which prevailed during the Imperial regimes. On this basis, the urban land tenure system resolved the problem of access to land by granting every urban dweller free access to urban land at a maximum of 500 square meters (Urban Land Proclamation No. 47/1975, 1975, Article 5(1)). Moreover, it also abolished the urban landlord and tenant relationship and further made tenants to be free from payment to the landowner of rent, debt, and any other obligation (Urban Land Proclamation No. 47/1975, 1975, Article 6(1)). Furthermore, at this juncture, it has to be noted that there was also reduction in the amount of monthly house rent, which ranges from 50 to 15 percent based on the pervious amount (Urban Land Proclamation No. 47/1975, 1975, Article 20). Generally, it is possible to conclude that the Derg regime's urban land tenure system ensured land equity-equitable access to urban land.

In view of urban land tenure security too, the Derg regime's urban land tenure system introduced different changes which affected it. Frist in terms of the robustness of land rights, the tenure system outlawed private ownership of land and in place urban landholders were granted with perpetual possessory rights with the duty of paying annual land rent (Urban Land Proclamation No. 47/1975, 1975, Article 5(1) and Article 9). It had expressly prohibited transfer of urban land through sale, antichresis, mortgage, lease, donation or through any other means (Urban Land Proclamation No. $47 / 1975,1975$, Article 4). It even restricted transfer of the urban land rights in the form of inheritance to only spouses or children upon death (Urban Land Proclamation No. 47/1975, 1975, Article $5(1))$. These changes illustrate the fact that the breadth of land rights given to urban landholders was significantly narrowed, highly limited, and that basic property rights in land were not granted.

Nevertheless, with regard to urban houses, save the preemption right of the government, the tenure system did entitle the house owners to the right to transfer urban houses through succession, sale or barter free (Urban Land Proclamation No. 47/1975, 1975, Article 12(1)). Still, the owners were not at liberty to transfer their house to whomsoever they wish since the system had entitled the government with preemption right.

In relation to assurance of land rights, the Derg regime's urban land tenure system also introduced different alterations, which in fact went against land tenure security of landholders. Frist, it authorized the Ministry of Public Works and Housing to retract possessory rights over any parcel not utilized within a specified period (Urban Land Proclamation No. 47/1975, 1975, Article 8(1)). One 
may guess the rationale behind this rule, to avoid unjustified delays in the construction activities in a bid to save unnecessary economic wastages. If the majority of the low-income people delay in completing the construction, it is only because of lack of money. Thus, it may be said that this measure was unrealistic taking into consideration the ability of the majority of the society and would threaten the land tenure security of the then urban landholders.

Second, like its predecessor and any other countries' land tenure system, the Derg regime's urban land tenure system authorized the government to expropriate urban land that is needed for public purposes, provided it "gives compensation in kind" to the individual, family, or organization possessing it (Urban Land Proclamation No. 47/1975, 1975, Article 8). However, this stipulation had some elements which affected the land tenure security of the holders. One thing, it failed to define what constitutes "public purpose" and this situation in turn opened a way for abuse and granted the government broad authority; and it created the risk of losing land rights to discretionary bureaucratic behavior. Additionally, the landholders were not certain as to when the government could expropriate their land. For the other thing, even though the land tenure system had required the compensation paid thereto to be in kind, it did not indicate whether locational value and the size of the land to be given as compensation was taken into account. Thus, it left open the possibility of the landholder to be under-compensated and since most landholders were in a poor political and/ or normative position to complain about treatment received under expropriation proceedings, they were left without recourse (Cohen \& Koehn, 1978).

Concerning enforceability of land rights, the Derg regime's urban land tenure system also incorporated some modifications. Specifically, the tenure system established three level judicial tribunals of local institutions, known as the cooperative society of urban dwellers, as special bodies to assume exclusive jurisdiction over disputes between urban dwellers involving urban land and housing (Urban Land Proclamation No. 47/1975, 1975, Article 27 through 30). Besides internal appeal, the decisions rendered by these tribunals were final and it was not allowed to appeal to a presumably independent court of law (Urban Land Proclamation No. 47/1975, 1975, Article 30). In connection to expropriation as well, the tenure system did not expressly grant the landholder the right to bring a legal action against the state on any grounds. Rather it denied landholder standing to initiate civil suits that challenge the legality of any action taken pursuant to the provisions of the legislation that defined the tenure system (Urban Land Proclamation No. 47/1975, 1975, Article 40). All of these restrictions had the implication of impeding the land tenure security of urban landholders. Thus, it is possible to argue that the arrangement set in the Derg regime's urban land tenure system was for the state to replace all former landlords.

\section{Urban Land Tenure System and Security of Current (EPRDF) Regime}

After the downfall of the Military Junta, Derg, in 1991, the current government has adopted peoples and state joint ownership of land in general, has introduced an urban land tenure system that requirees lease as a cardinal means of acquiring urban land through the enactment of the first urban lands Lease Holding Proclamation No. 80/1993 (1993). This proclamation was later repealed and replaced by lease proclamation No. 272/02, which itself was repealed in 2011 , by the currently prevailing lease proclamation No. 721/2011 (2011).

The first proclamation that defined the current urban land tenure system provided the following points as reason for replacement of the Derg regime's urban land tenure system: (Urban Lands Lease Holding Proclamation No. 80/1993, 1993, Preamble).

- to make the utilization of urban land in a manner that can satisfy housing needs of the various section of the population; 
- to rectify the inherent problem of the pervious urban land tenure system, which failed to provide for the value of land utilization and to rectify the nontransparency, corruption and discriminatory treatment that the permit system created;

- to provide the value of land in terms of money that would go along with the free market principle, which is the main economic policy of the transitional government and; to collect urban revenues that would help to finance different urban infrastructures, housing needs of urban dwellers;

- to provide for planned and economic development of urban centers with controlling appropriations of unjustified gain and with creating favorable conditions for investors that would enable them to participate in the economic development of urban centers.

After providing these justifications, this legislation delimited its scope of application for urban land acquired after the promulgation of it (Urban Lands Lease Holding Proclamation No. 80/1993, 1993, Article 3(1)). Those urban lands held before the coming into effect of the current urban land tenure system - through the then permit system adopted under Derg regime's land tenure systemcontinued to be regulated by the Derg regime's land tenure system. However, whenever houses built on permit holdings were to be transferred to others through any other means other than that of inheritance, it was stated that the person to whom the said house is transferred could only hold the land according to the lease holding system (Urban Lands Lease Holding Proclamation No. $80 / 1993$, Article 3(1) and (2)). This situation gave rise to the existence of double urban land tenure system at that time. Therefore, during this time the land tenure security of permit holders was treated in the same fashion with the Derg regime.

However, after 9 years, the current regime also made some adjustment on the urban land tenure system via the re-enacted Urban Lands Lease Proclamation No. 272/2002 (2002). The main reasons that necessitated the adjustments on the tenure system were specifically stated under the preamble of the Proclamation No.272/2002 (2002). Accordingly, making leasehold system consistent with the principle of free market which would help to achieve overall economic, social and progressive urban development; the need to make leasehold system an exclusive mode of urban land acquiring system; the need to use urban land in conformity with the master plan; and the need to provide for transparent and expedient order, which could enable to resolve claims related with infringement of once legal right and benefits were cardinal reasons for the modifications (Urban Lands Lease Holding Proclamation No. 272/2002, 2002, Preamble).

Among the prominent new modifications made under the urban land tenure system through Lease Proclamation No. 272/2002 (2002) was the extension of the application lease landholding system for all those urban lands held by the previous permit holders. However, it has to be noted that the application of leasehold system on permit holders was suspended until the then regional and city governments decided the time and conditions under which permit holders could be converted in to leasehold system (Urban Lands Lease Holding Proclamation No. 272/2002, 2002, Article 3(1) and (2)).

Nonetheless, before the concerned regional and city governments came up with those specific conditions that would prescribe the time and conditions for the conversion this law was repealed and ceased to exist. Therefore, defacto the then permit holdings were continued to be regulated by the Derg regime's land tenure system and the urban land tenure security of permits holders were undermined in the same fashion with the Derg regime. Moreover, the other modification added in this legislation was to outlaw the requirement of conversion of permit holdings to leasehold system in cases when transferred to third parties even through all means other than inheritance. 
However, again after 9 years, certain modifications have been introduced to the urban land tenure system via currently prevailing Urban Lands Lease Holding Proclamation No. 721/2011 (2011). The justification for the modification is twofold: meeting the rapid and exponential increase in demand for urban land due to rapid economic increase registered across the country; and ensuring good governance so as to achieve efficient, effective, equitable, transparent, accountable, and wellfunctioning land administration system (Urban Lands Lease Proclamation No. 721/2011, 2011, Preamble).

Nevertheless, ever since its enactment in November 2011, even more than ever before, this Proclamation that defined the urban land tenure system baffled most Ethiopians throughout the country and those living abroad. The very first criticism of the proclamation began on the procedure of its enactment. Here it is underscored that the bill for the law did not go through the traditional procedure of being tabled to the parliament by the member of the parliament, discussed by the relevant standing committee for review, and sent back to the parliament for the discussion with the public before being passed. In addition, the most contentious issues raised by the public have been the way the tenure system defined in this proclamation treats permit holders (old possessors) and some new amendments it introduced that existed under the previous lease proclamation. In fact, there is a need for critical examination of any changes and amendments this proclamation brought to the urban land tenure system. The public uproar it ignited particularly from those permit holders deserves in-depth analysis in light of an objective element of urban land tenure security. Consequently, following is a detailed analysis of each aspect of objective tenure security.

\section{Clarity and Breadth of Land Rights}

Under the currently prevailing urban land tenure system, permit holdings are mandatorily required to be converted into a lease holding system. Nevertheless, this would happen based on the modality of conversions that will be determined by the Council of Ministers on the basis of detailed study (Urban Lands Lease Proclamation No. 721/2011, 2011, Article 6(1)). Yet, the Council has determined the modality and this situation puts the permit holdings in a suspended status. Thus, it is not clear what types of land rights permit holders have on their urban parcel until the conversion.

Moreover, though they are certain about the mandatory conversion of their holdings into leasehold system, they are uncertain about the modality-the nature of obligations on them in the process of conversion. Regarding whether they are going to pay lease price for the mere conversion of their holdings into leasehold system even in the absence of any transaction, the tenure system has express stipulation. Accordingly, permit holders are mandatorily required to pay the benchmark lease price of the locality that would be determined by taking into account the cost of infrastructural development, demolition costs as well as compensation to be paid to displaced persons in case of built up areas, and other relevant factors (Urban Lands Lease Proclamation No.721/2011, 2011, Article 2(11) and 6(7)). Nonetheless, how much to pay, how to afford the money needed, and what will happen if the money needed is not affordable-these are some of the uncertainties facing the permit holders.

In terms of breadth of land rights again, the EPRDF urban land tenure system determination has the effect of narrowing the number of land rights of permit holders even compared with lease holders. The first excluded property rights in land of permit holders is the right to use the land rights as means of collateral to access loans and as a capital contribution. When we see the Urban Land Lease Proclamation No. 721/2011 (2011) that defines the urban land tenure system in this regard it states that "...a lessee may...use it as a collateral or capital contribution to the extent of the lease amount already paid" (Urban Lands Lease Proclamation No. 721/2011, 2011, Article 24(1)). A contrario sensu of this stipulation indicates that the permit holder is not entitled to exercise these property rights 
since he is not a lessee. Contrarily, we may extend the application of this provision to permit holders by argumentum a simili. Nevertheless, considering the absence of lease payment in case of permit holdings-for they acquired for free, this right is excluded de facto. These forms of restrictions were not introduced in the two earlier legislations that had defined the post-1991 urban land tenure system the EPRDF regime.

The other restriction imposed by the current urban land tenure system of Ethiopia on the property rights in land of permit holders is the right to transfer the land rights through sale. According to the tenure system defined in the Urban Land Lease Proclamation No. 721/2011 (2011) in case of sale of property rights in land or a property attached on permit holdings, beside the land holding system converted to lease holding system, a lease price calculated in the rate of benchmark lease price of the locality is required to be paid to the government (Urban Lands Lease Proclamation No. 721/2011, 2011, Article 6(3) and (7)). In fact, it is not clear as to who should pay it - the permit holder or the buyer. Irrespective of the payer of the lease price, this obligation restricts the opportunity of the permit holder to exercise this right. In case a buyer is required to pay it, he will not opt to buy permit holdings or property on permit holding. This is because it subjects him to carry out double payments for purchase of a single land rights or property on such land. In a situation where a permit holder is required to pay the lease price too, a buyer may not prefer to buy permit holdings or property on permit holdings; since a seller fixes the price thereto by taking into account the amount of the lease price that he is going to pay. Therefore, the right to transfer the land rights on permit holdings through sale is excluded practically.

Especially in cases when a permit holder is involved in transfer of his land rights on bare land or halfconstruction through sale it is not free from interference of state; and even the land tenure system has envisaged a rule that deprives him of the economic benefit derived from the transfer of thereto. These rules were enshrined for a lease holding. Nevertheless, we can extend their application to permit holdings analogically. On this basis, first he is required to follow transparent procedures of sale to be supervised by a regional body or a city administration vested with the power to administer and develop urban land (Urban Lands Lease Proclamation No.721/2011, 2011, Article 24(2)).

With regard to the economic benefit derived from the sale, the permit holder is entitled to the effected payment to the state including interest (though non-existent in the case at hand since the permit holder had not effected any payment to the state in acquiring the land), calculated at bank deposit rate; the value of the already executed construction and 5 percent of the transfer lease value (Urban Lands Lease Proclamation No.721/2011, 2011, Article 24(3)). Particularly, the economic benefit retained by a permit holder is insignificant compared to the remaining balance paid to the government.

\section{Duration of Land Rights}

The other important objective element of land tenure security which the EPDRF regime's urban land tenure system has introduced is a change in the length of time for which land rights are valid. As mentioned previously, in the two antecedent urban land tenure systems the urban land rights were granted in perpetuity in the country. However, the currently prevailing land tenure system is for a definite period of time which varies depending on the development level of the urban centers and the nature of activities to be carried out on the land. This time limit on the land rights of permit holders is deduced from the tenure system's requirement of converting permit holdings to the lease system. As a result, the duration of the land rights extends from 99 years for residential house, science and technology, research and study, governmental offices, charitable organizations, and religious institutions to 15 years for urban agriculture (Urban Lands Lease Proclamation No.721/2011, 2011, Article 18). 
The problem for the land tenure security of permit holders in this regard is further exaggerated by the failure of the tenure system to adopt automatic renewal of the period, subjecting it to bureaucratic and arbitrary discretionary power. Permissively, the state officer renews the period only if the landholder applies in writing to the appropriate body within 10 to 2 years before the expiry of the previous lease period (Urban Lands Lease Proclamation No. 721/2011, 2011, Article 19(1) and (2)). The appropriate body should inform its decision in writing to the applicant within a year from the date of submission of the application. In failure to do so, the period is presumed to be renewed on the prevailing benchmark lease price. However, the tenure system has not expressly provided the grounds by which the lease periods are not renewed (Urban Lands Lease Proclamation No. 721/2011, 2011, Article 19(3)). This situation in return subjects the landholder to subjective, unpredictable, uncertain, and abusive decisions.

\section{Assurance of Land Rights}

The third aspect of the objective element of land tenure security is creation of a mechanism of effective legal protection against eviction or arbitrary curtailment of land rights of landholder. For the realization of assurance of land rights, the land tenure system must clearly and in a limited manner define the grounds by which the landholder losses his land rights, and provide an adequate compensation scheme (Rahmato, 2004, 2011; FAO, 2008; Migot-Adholla et al., 1994; Deininger, 2003).

The EPRDF regime's urban land tenure system has taken some measures that are related to assurance of land rights of permit holders. One of the grounds for loss of a permit holder's land rights in the current regime is reduction of the parcel in order to respond to with the approved national standard and urban plan (Urban Lands Lease Proclamation No. 721/2011, 2011, Article $6(2 a))$. This justification to deprive the land rights of permit holders is deemed necessary by the government to ensure urban beauty and efficient land utilization. In fact, what is expected from the legal environment is to create a foundation for adequately compensating the permit holder in this regard. However, when we examine the land tenure system it has not considered the loss of land right as compensable interest. It only provides compensation to be paid for any property on the land so reduced (Urban Lands Lease Proclamation No. 721/2011, 2001, Article 6(2a)). Thus, one can easily notice that the state is given an immense power to take urban lands from the property of a permit holder without giving any compensation for it.

The main grounds whereby permit holder loses his land rights is in the case of expropriation. Actually, expropriation of land rights for public purpose is an inherent right and power of the state and it even exists in most individualistic systems because of the need to have rights holder contribute to the broader public good (Deininger, 2003). However, it needs to keep a balance between the public need for land and provision of land tenure security to the landholder. This balance would be realized by using this power in a limited manner for the benefit of society at large and under the provision of a basis of just compensation (Deininger, 2003; FAO, 2008; Migot-Adholla et al., 1994; Rahmato, 2004; Seifu, 2009).

Under the EPRDF regime's urban land tenure system, a permit holder's urban land right is subjected to expropriation for public interest and upon payment of compensation. "Public interest" as a ground for expropriation of land rights of a permit holder is defined as "the use of land defined as such by the decision of the appropriate body in conformity with urban plan in order to ensure the interest of the people to acquire direct or indirect benefits from the use of the land and to consoledate sustainable socio-economic development" (Urban Lands Lease Proclamation No.721/2011, 2011, Article 2(7)). This definition adopted under the urban land tenure system of the EPRDF regime is so broad and left to be determined by the administrative authority that is empowered to expro- 
priate the land. It is interpreted widely to include both the direct and indirect benefits the society derives from the proposed activity to which the urban land is expropriated. Moreover, the regime has exercised discrimination on the meaning of public interest for expropriation of lease holding and permit holdings. Consequently, lease holdings are expropriated only when they are required for the development activity to be undertaken by the government (Urban Lands Lease Proclamation No. 721/2011, 2011, Article 26(3)). Whereas permit holdings can be expropriated for whatsoever purpose carried out by whosoever, if the administrative organ regards it as a "public interest." However, an exercise in compulsory acquisition is more likely to be regarded as legitimate if land is taken for a purpose clearly identified in legislation (FAO, 2008). Further, in order to reduce the scope for arbitrary and discretionary action by individual bureaucrats, legislations should be clear enough in the circumscription of the state's right to expropriate land in noticeably identifiable public interest (Deininger, 2003).

With regard to the extent of compensation awarded for the loss of land rights of a permit holder under expropriation, it is required to be adequate or just compensation. The examination of the current urban land tenure system of Ethiopia reveals that the kind of compensation is in kind, landto-land compensation - substitute urban land. In this form of compensation, the adequacy is determined based on the size of the substitute plot of land and location of it. This is to mean that the substitute land should be the same in size and located in the convenient place like the expropriated land. The EPRDF regime's urban land tenure system has empowered regional and city administration to discretionarily determine the size and location of substitute land. As such, it has not expressly required the size of the substitute land to be equivalent nor situated in an equally convenient location. Thus, the substitute land granted to a permit holder for expropriation of his permit holding may be lesser in size and located in inconvenient place/outskirts or it may not be near to different infrastructures, such as schools, roads, and health centers, as the expropriated land. Furthermore, when it is not possible to find identical land in its every aspect, the tenure system has not provided any leeway to compensate such differences in monetary term. This inadequate compensation for land taken under the powers of eminent domain can create a high degree of tenure insecurity and anxiety among permit holders (Bekure et al., 2006). Therefore, this stipulation implies that the state has extensive power of expropriating land without fair compensation.

\section{Enforceability of Land Rights}

One of the indicators for the existence of land tenure security of permit holders is the protection of the latter from dispossession by outside sources including the government and the elimination of the risk of losing the land rights to discretionary bureaucratic behavior (Deininger, 2003). In other words, objective tenure security depends inter alia on the likelihood that land rights will be violated; and the ability to obtain redress by an authoritative institution in such cases (FAO, 2008).

Accordingly, the land tenure system should guarantee the procedural rights of the affected permit holder, including the right to be heard, and the right to appeal to an independent body during compulsory acquisition so that a balance is maintained between the public need for the land and provision of land tenure security of permit holders (FAO, 2008). Thus, in order to maintain tenure security, the loss of landholder's rights should be a result of due process and the decision of a court of law. Genuine tenure security will be realized when no decision on land rights is binding on the holder unless it is made through the legal process and is the decision of legitimate courts (MigotAdholla et al., 1994).

In relation to expropriation, three matters may need the decision of a court of law. These are the purpose of the project, the procedures used to implement compulsory acquisition and compensation value (FAO, 2008). With regard to the purpose of the project, the permit holder should be entitled to challenge the claim that the project serves the public purposes for which compulsorily 
acquisition is allowed or that their specific parcels are needed for the project. The permit holder should be allowed to present the case that the project would be best located elsewhere (FAO, 2008). It is difficult for affected permit holders to challenge the purpose of projects in countries that have no clearly defined purposes for which land can be compulsorily acquired. On the other side, procedural irregularities may occur due to expropriators' failure to observe different procedural requirements necessary to ensure due process. Thus, it happens that the acquisition takes place without the affected permit holder being informed of the process, or there is a failure to include all required information in a notice of compulsory acquisition; unreasonable haste in pursuing acquisition; improper processing of compensation claims; delay in payment or payment to the wrong person (FAO, 2008). These problems jeopardize the legitimacy of the process.

The final base that needs the decision of a court of law is regarding determination of the amount/value of compensation. Particularly, if the amount of compensation is believed to be inadequate the affected permit holder may bring an appeal to a court of law. However, under the EPRDF regime urban land tenure system appeal to a presumably independent court of law on the aforementioned three matters of expropriation is prohibited (Urban Lands Lease Proclamation No.721/2011, 2011, Article 29(3)). While there is a way for appeal to an administrative tribunal, this prohibition avoids the possibility of checking the acts of the executive by the judiciary and it highly perpetuates the land tenure insecurity of permit holders.

\section{Conclusion}

Examining the post-1991 urban land tenure reform, one could argue that it has incorporated changes that can reduce the objective land tenure security of permit holders. It might also be noted that the comparison of it with the Derg and the Imperial regimes' urban land tenure system reveals that the objective land tenure insecurity of permit holders is highly perpetuated by the EPRDF regime's urban land tenure system. In fact, this does not mean that the previous two urban land tenure systems are devoid of any specific provisos that would emasculate the objective element of urban landholder's land tenure security, yet one would have expected improvement on these issues rather than backsliding.

\section{References}

Alston L.J., Harris E., \& Mueller B. (2009). De Facto and De Jure property rights: Land settlement and land conflict on the Australian, Brazilian and US frontiers. (NBER Working Paper No. w15264). Cambridge, MA: National Bureau of Economic Research.

Bekure S., Mulatu A., Abebe G., \& Roth M. (2006). Removing limitations of current Ethiopian rural land policy and land administration. Washington, DC: Workshop on Land Policies \& Legal Empowerment of the Poor.

Bodurtha P.J. (2011). Land reform in Ethiopia; recommendations for reform. Addis Abeba: Solidarity Movement for a New Ethiopia (SMNE).

Cohen J.M., \& Koehn P.H. (1978). Rural and urban land reform in Ethiopia. African Law Studies, 14, 3-61

Deininger K. (2003). Land policies for growth and poverty reduction: A World Bank policy research report. Washington, DC: The World Bank and Oxford University Press.

Ethiopia. (1931). The Constitution of the Empire of Ethiopia (Established in the reign of His Majesty Emperor Haile Selassie I). Addis Ababa: Berhanena Selam Printing.

FAO. (2002). Land tenure and rural development, land tenure studies 3. Rome: FAO.

FAO. (2008). Compulsory acquisition of land and compensation (Land Tenure Studies 10). Rome: 
FAO.

Markakis J. (1974). Ethiopia: Anatomy of traditional polity. Oxford: Clarendon Press.

Migot-Adholla S.E., Benneh G., Place F., \& Atsu S. (1994). Land, security of tenure, and productivity in Ghana. In Bruce John W., \& Migot-Adholla Shem E. (Eds), Searching for land tenure security in Africa. Washington, DC: The World Bank and International Bank for Reconstruction and Development.

Pankhurst R. (1961). Menelik and the foundation of Addis Ababa. Journal of African History, 2(1), 103-117. Crossref

Pankhurst R. (1966). State and land in Ethiopian history. Addis Ababa: Oxford University Press.

Rahmato D. (2004). Searching for tenure security? The land system and new policy initiatives in Ethiopia (Discussion Paper No. 12). Addis Ababa: Forum for Social Studies.

Rahmato D. (2011). Land to investors: Large-scale land transfers in Ethiopia. Addis Ababa: Forum for Social Studies.

The Empire of Ethiopia. (1955). Revised Constitution of the Empire of Ethiopia. Addis Ababa.

Seifu G. (2009). Rural land tenure security in the Oromia national regional state. In Abdo Muradu (Ed.), Land law and policy in Ethiopia since 1991: Continuities and challenges. Addis Ababa: Addis Ababa University Press.

Teklu T. (2005). Land scarcity, tenure change and public policy in the African case of Ethiopia:

Evidence on efficacy and unmet demands for land rights (Paper 89). International Conference on African Development Archives, Addis Ababa, Ethopia.

The Civil Code of the Empire of Ethiopia. (1960). Negarit gazeta, extra ordinary proclamation No. 165 of 1960, year 19. Addis Ababa: Berhanena Selam Printing.

Urban Land Proclamation No. 47/1975. (1975). Government ownership of urban lands and extra houses proclamation. Addis Ababa: Berhanena Selam Printing.

Urban Lands Lease Holding Proclamation No. 272/2002. (2002). Federal negarit gazeta of the federal democratic Republic of Ethiopia, 8th year No. 19. Addis Ababa: Berhanena Selam Printing. Urban Lands Lease Holding Proclamation No. 80/1993. (1993). A proclamation to provide for the lease holding of urban lands. Addis Ababa: Berhanena Selam Printing.

Urban Lands Lease Proclamation No. 721/2011. (2011). A proclamation to provide for lease holdings of urban lands. Addis Ababa: Berhanena Selam Printing.

WeldeGebriel N. (2005). Who are benefiting? The land lease policy (Unpublished master's thesis). Addis Ababa University, Addis Ababa.

WoldeMariam M. (1970). Problems of urbanization. (Proceeding of the Third International Conference of Ethiopian Studies). Addis Ababa: Institute of Ethiopian Studies.

Brightman Gebremichael has studied Law (LL.B. and LL.M.) in Bahir Dar University and taught at Wollo University. He has served as the Dean and Free Legal Aid Director of the Law School of Wollo University from 2014 to 2015. Currently, he is an African Pathway-NIHSS-sponsored LL.D. student of Law at the University of Pretoria 